\title{
Zgodnja navezanost med malčkom in staršem kot napovednik kakovosti prijateljstva otrok v srednjem otroštvu
}

\author{
Nika Čermak ${ }^{1 *}$ in Ljubica Marjanovič Umek ${ }^{2}$ \\ ${ }^{1} \mathrm{Ig}$ \\ ${ }^{2}$ Oddelek za psihologijo, Filozofska fakulteta, Univerza v Ljubljani
}

\begin{abstract}
Povzetek: Osrednja predpostavka teorije navezanosti je, da se varnost navezanosti in model zgodnjega odnosa med dojenčkom in staršem ali skrbnikom odražata tudi v drugih medosebnih odnosih, vključno s prijateljstvi, skozi življenje. Odnos med otrokom v različnih razvojnih obdobjih in staršem ali skrbnikom tako velja za enega pomembnih napovednikov socialnega razvoja otrok. $\mathrm{V}$ pričujoči raziskavi smo preučili vzdolžno povezavo med zgodnjo navezanostjo malčkov in kakovostjo njihovih prijateljstev $\mathrm{v}$ srednjem otroštvu. V vzorec je bilo vključenih 129 malčkov ( 52 \% dečkov), iz prvotnega vzorca pa je pri drugem merjenju sodelovalo 118 otrok. Pri starosti 15 mesecev smo navezanost malčkov ocenili z Vprašalnikom o navezanosti (AQS), pri 9 letih pa smo kot mere kakovosti prijateljstva uporabili samooceno, oceno opazovalcev ter sociometrično preizkušnjo. Med varnostjo navezanosti in opazovano kakovostjo prijateljstva obstaja pomembna povezanost, medtem ko navezanost ni bila neposredno povezana s samooceno kakovosti prijateljstva in številom recipročnih prijateljstev otrok. Predpostavili smo tudi model poti, s katerim smo preverili povezave med navezanostjo in kakovostjo prijateljstva. Individualna kakovost interakcije otrok se je izkazala kot pomemben mediator varne navezanosti pri napovedovanju medvrstniške kompetentnosti, ki se kaže v številu recipročnih prijateljstev. Statistično pomembne, a zmerne povezave kažejo na zmeren učinek varne navezanosti na kakovost prijateljstva v srednjem otroštvu.
\end{abstract}

Ključne besede: navezanost, prijateljstvo, medvrstniški odnosi, psihosocialni razvoj, vzdolžna študija

\section{Early toddler-parent attachment as a predictor of the quality of children's friendship in middle childhood}

\author{
Nika Čermak ${ }^{1^{*}}$ and Ljubica Marjanovič Umek² \\ ${ }^{1} \mathrm{Ig}$, Slovenia \\ ${ }^{2}$ Department of Psychology, Faculty of Arts, University of Ljubljana, Slovenia
}

\begin{abstract}
The central premise of the attachment theory is that attachment security and the model of early child-parent relationship is reflected in the child's interpersonal relationships across the life span, including his/her friendships. The child-parent relationship at different developmental stages is thus considered one of the most important predictors of social development in children. The present study examined the longitudinal connection between early attachment of toddlers and the quality of their friendships in middle childhood. The sample consisted of 129 toddlers (52\% boys), from which 118 participated in the second wave of data collection. Toddler attachment was assessed with Attachment Q-sort at the age of 15 months, while friendship quality at 9 years was assessed using three measures, namely a self-report, observations and a sociometric measure. We found a significant correlation between attachment and observed friendship quality, while attachment was not directly related to self-reported friendship quality and number of reciprocal friendships. Furthermore, we examined links between attachment and friendship quality by proposing a path model. Individual quality of child interaction was found to be a significant mediator of the path from attachment security to later peer competence, as reflected in the number of reciprocal friendships. Significant, but moderate correlations suggest a moderate effect of secure attachment on friendship quality in middle childhood.
\end{abstract}

Keywords: attachment behavior, friendship, peer relations, psychosocial development, longitudinal studies

\footnotetext{
*Naslov/Address: Nika Čermak, 1292 Ig, nika.cermak@gmail.com
} 
Eno izmed načel Bowlbyeve teorije navezanosti pravi, da varnost odnosa med mamo in otrokom vpliva na kakovost otrokove navezanosti na druge objekte navezanosti (Bretherton, 1985). Podporo slednjemu načelu zagotavlja več izsledkov raziskav, da varna navezanost malčkov na starša ali skrbnika podpira raziskovanje okolja (Ainsworth idr., 2015) ter razvoj odnosov in interakcij z vrstniki (Kerns in Brumairu, 2016; Sroufe in Waters, 1977). Malčki, ki so varno navezani na starše oz. skrbnike, prevzamejo odziven slog interakcije v drugih odnosih in so običajno uspešnejši pri oblikovanju in ohranjanju pozitivnih odnosov z vrstniki (npr. Cohn, 1990; LaFreniere in Sroufe, 1985; Park in Waters, 1989). Navezanost na referenčno osebo lahko vpliva na prijateljstva tudi preko koncepta notranjih delovnih modelov (Booth-LaForce in Kerns, 2009; Bowlby, 1973; Bretherton, 2005). Ponotranjeni notranji delovni modeli vplivajo na otrokovo vedenje $\mathrm{v}$ sedanjosti in na uspeh $\mathrm{v}$ bodočih odnosih. Varno navezani malčki razvijejo delovne modele, ki jih vodijo k pričakovanjem o toplih, skrbnih in odzivnih vrstnikih. Posledično varno navezani malčki veliko verjetneje vstopajo v vrstniško interakcijo in se v primerjavi z ogroženo navezanimi vrstniki na približevanje vrstnikov odzivajo sodelovalno, samozavestno in imajo pozitivna pričakovanja o odnosih (Bagwell in Schmidt, 2011; Ladd, 2016). Koncept notranjih delovnih modelov predvideva, da je prav intimnost v zgodnjih družinskih odnosih najpomembnejša osnova tesnih prijateljstev $\mathrm{v}$ otroštvu in mladostništvu (Bagwell in Schmidt, 2011). Raziskave o navezanosti in prijateljstvu pogosto temeljijo na teoretičnem konceptu notranjih delovnih modelov in četudi so povezave med navezanostjo in prijateljstvom popolnoma skladne s teoretičnimi idejami vloge in vpliva notranjih delovnih modelov, pa je obstoj slednjih sicer težko dokazljiv (Bagwell in Schmidt, 2011).

Številne prečne (npr. Lansford, 2004) in vzdolžne raziskave (npr. Bagwell in Schmidt, 2011; Main idr., 1985; McDowell in Parke, 2009) ponujajo dokaze o povezanosti vzorcev navezanosti $\mathrm{s}$ kakovostjo otrokovih vrstniških odnosov v predšolskem okolju. Varno navezani otroci so tako v zgodnjem otroštvu bolj odzivni, družabni, empatični in manj agresivni do neznancev kot otroci, ki so ogroženo navezani na mamo (LaFreniere in Sroufe, 1985; Waters idr., 1979). Varno navezani otroci imajo v zgodnjem otroštvu tudi manj negativnih interakcij $\mathrm{z}$ bližnjim prijateljem (Youngblade in Belsky, 1992). Izsledki raziskav so pokazali, da so varno navezani malčki med prvim in drugim letom bolj dejavni, družabni in sodelovalni $\mathrm{v}$ odnosih s predšolskimi vrstniki (Waters idr., 1979), prav tako se v medvrstniških odnosih pogosteje vedejo pozitivno in imajo $\mathrm{v}$ primerjavi $\mathrm{z}$ ogroženo navezanimi vrstniki bolj kakovostne medvrstniške odnose (LaFreniere in Sroufe, 1985). Izsledki prečnih (npr. Scharf, 2014; Scharf idr., 2016) in vzdolžnih (npr. Pallini idr., 2014) raziskav so si tako v splošnem enotni, da zgodnja varna navezanost na starša ali skrbnika spodbuja razvoj socialnih spretnosti in medvrstniško kompetentnost otrok, slednja pa je povezana z lažjim sklepanjem prijateljstev, ohranjanjem prijateljstev in višjo kakovostjo prijateljstev v srednjem otroštvu (npr. Berndt, 1996; Parker in Asher 1993). Sroufe idr. (1999) poročajo tudi o nekaj pomembnih empiričnih ugotovitvah o zgodovini navezanosti kot napovedniku pomembnih značilnosti medvrstniških odnosov. Zgodovina navezanosti je pojasnila $13 \%$ variance kompetentnosti v prijateljskih odnosih v srednjem otroštvu, devet let po ocenjevanju kakovosti navezanosti.

Raziskovalci so v več prečnih raziskavah (npr. Clark in Ladd, 2000; Wood idr., 2004) preučevali tudi povezanost med navezanostjo otroka na mamo in številom prijateljstev, ki jih otrok razvije, pri čemer so ugotovili pomembno povezanost med kakovostjo navezanosti in številom recipročnih prijateljev. Varna navezanost na mamo v zgodnjem otroštvu je tako napovedala število prijateljstev, ki jih predšolski otroci sklenejo z vrstniki v skupini (Sroufe, 1983), in število nominacij "najboljši prijatelj", ki jih otroci prejmejo eno do dve leti kasneje v sociometrični preizkušnji (Wood idr., 2004).

Da bi naredili sintezo raziskav navezanosti in medvrstniških odnosov, so Schneider in sodelavci (2001) izvedli metaanalizo 63 raziskav, izvedenih med leti 1970 in 1998, ki so obravnavale navezanost kot napovednik medvrstniških odnosov otrok. Skupna velikost učinka varne navezanosti na kakovost medvrstniških odnosov je bila 0,20 , ugotovili pa so tudi, da je bila povprečna velikost učinka pomembno višja pri otrocih v srednjem otroštvu (v primerjavi z otroki v zgodnjem otroštvu) in pri merah izida, ki se nanašajo na tesna prijateljstva (v primerjavi $\mathrm{z}$ drugimi, manj intimnimi vidiki socialne kompetentnosti z vrstniki). Velikost povezanosti med navezanostjo in medvrstniškimi odnosi se je s starostjo otrok večala, kar bi lahko pripisali višji stabilnosti notranjih delovnih modelov pri otrocih ter predvidevanju, da si starševski in medvrstniški odnosi z višjo starostjo otrok postajajo bolj podobni. Tudi novejše raziskave kažejo na dosledno povezanost varne navezanosti z višjo kakovostjo medvrstniških odnosov (Groh idr., 2014; Kerns in Brumariu, 2016), ugotovitve metaanalize, ki so jo izvedli Schneider in sodelavci (2001) pa podpirajo tudi rezultati novejše metaanalize, ki je preučila raziskave, izvedene po letu 1998 (Pallini idr., 2014).

Varna navezanost, ocenjena $\mathrm{v}$ obdobju dojenčka, v zgodnjem in srednjem otroštvu, je povezana z višjo vrstniško kompetentnostjo, kakovostjo prijateljstva in priljubljenostjo med vrstniki v zahodnih kulturah (Groh idr., 2014, Pallini idr., 2014), enako pa velja tudi za bolj kolektivistične kulture (npr. Izrael), kar nakazuje na univerzalnost povezave med varno navezanostjo in višjo kakovostjo prijateljstva (Scharf idr., 2016). Vendar pa nekatere vzdolžne raziskave niso podprle neposredne povezanosti med varno navezanostjo in kakovostjo prijateljstva (npr. Schwarz idr., 2012; Youngblade idr., 1993).

Predstavljene ugotovitve preučevanja zgodnjega odnosa med primarnim skrbnikom in malčkom ter medvrstniškimi odnosi, ki jih otrok oblikuje $\mathrm{v}$ otroštvu, potrjujejo razvojni pomen zgodnje navezanosti za kasnejšo socialno kompetentnost. Kljub precejšnjemu številu raziskav $\mathrm{s}$ področja navezanosti in prijateljstva, pa se večina raziskav nanaša na obdobje zgodnjega otroštva in manj na obdobje srednjega otroštva. Prav tako je precej predstavljenih raziskav zasnovanih prečno. $\mathrm{V}$ tovrstnih raziskavah so se raziskovalci ukvarjali predvsem s preučevanjem povezanosti med zgodnjo navezanostjo in kakovostjo prijateljstev ter 
povezanostjo zgodnje navezanosti s številom prijateljstev. V literaturi pa nismo zasledili raziskav, ki bi poskušale zajeti vse navedene spremenljivke in ugotoviti, kakšna je njihova medsebojna povezanost. Predpostavili smo, da če je otrok v svojih odnosih z najboljšimi prijatelji empatičen, recipročen, nudi pomoč, kaže naklonjenost do drugih in izraža pretežno pozitivna čustva, bo verjetno pridobil in ohranil več prijateljev. $\mathrm{S}$ tem smo v naši raziskavi želeli odgovoriti na vprašanje, ali je kakovost prijateljskih odnosov mediator odnosa med zgodnjo varno navezanostjo in številom recipročnih prijateljstev v srednjem otroštvu. Namen pričujoče raziskave je tako preučiti vzdolžno povezanost med kakovostjo zgodnje navezanosti malčkov na starše oz. skrbnike in kakovostjo njihovih prijateljstev v srednjem otroštvu. Predpostavili smo, da sta navezanost $\mathrm{v}$ obdobju malčka in kakovost prijateljstva v srednjem otroštvu pomembno pozitivno povezana ter da je varna navezanost $\mathrm{v}$ obdobju malčka pomemben napovednik pozitivnih vidikov prijateljske interakcije v obdobju srednjega otroštva, pri čemer smo predvidevali, da bolj kakovostne prijateljske interakcije verjetno prispevajo tudi $\mathrm{k}$ večjemu številu recipročnih prijateljev.

\section{Metoda}

\section{Udeleženci}

Raziskovalna vprašanja smo naslovili z uporabo dveh valov podatkov iz nizozemske vzdolžne študije Nijmegenska vzdolžna študija o razvoju dojenčkov in otrok (angl. The Nijmegen Longitudinal Study on Infant and Child Development), za katero so nam bile dostopne baze podatkov za nadaljnje raziskovanje. V začetni vzorec je bilo vključenih 129 15-mesečnih malčkov $\left(M_{\text {starost }}=15,1\right.$ meseca; $S D=0,25$; od tega $52 \%$ dečkov) in njihovih primarnih skrbnikov (Van Bakel in Riksen Walraven, 2002). Malčki in njihovi skrbniki so bili naključno izbrani na podlagi registra podatkov zdravstvenih domov v Nijmegenu ter so bili reprezentativni za nizozemsko populacijo glede na socialno-ekonomski status. Večina udeležencev je bila bele rase (98\%); v 126 družinah je bila mama primarni skrbnik. Iz prvotnega vzorca je v ocenjevanju pri starosti 9 let sodelovalo 118 otrok $\left(M_{\text {starost }}=9,3\right.$ leta, $\left.S D=0,20\right)$. Od 118 otrok so popolni podatki zbrani za 110 .

\section{Postopek in pripomočki za ocenjevanje navezanosti med malčkom in starši oz. skrbniki}

Podatki pri malčkih, starih 15 mesecev, so bili zbrani med obiskom na domu in med obiskom primarnega skrbnika $\mathrm{z}$ malčkom v laboratoriju raziskovalnega centra na Univerzi v Nijmegnu. Med obiskom na domu so raziskovalci posneli štiri videoposnetke starša in malčka, ki sta po navodilih izvajala naslednje naloge: odklenila škatlo-sestavljanko, sestavila lutko, sestavila sestavljanko, na koncu pa je starš malčku prebral niz kratkih slikanic. Vsaka naloga je trajala tri do štiri minute. Starši so lahko malčkom pomagali kadarkoli se jim je to zdelo potrebno. Preostali čas med obiskom na domu so raziskovalci malčka opazovali med prosto igro, medtem ko je starš izpolnil več vprašalnikov. Pri tem je imel starš več odmorov, med katerimi je bil popolnoma na voljo malčku. $\mathrm{V}$ laboratoriju je bil posnet skoraj identičen nabor situacij interakcije med staršem in malčkom, kot je bil posnet med obiskom na domu.

Za ocenjevanje malčkove navezanosti so raziskovalci uporabili nizozemski prevod Vprašalnika o navezanosti (angl. Attachment Q-sort-AQS; Waters, 1995), ki so ga za vrednotenje uporabili po zaključku 2-urnega opazovanju na domu. Devetdeset opisnih postavk vprašalnika AQS je bilo razdeljenih v devet kategorij. Postavke, ki najbolje opišejo značilnosti otroka so bile razvrščene na en konec distribucije (kategorije 9, 8 in 7), postavke, ki najslabše opišejo značilnosti otroka pa na drug konec distribucije (kategorije 3, 2, 1). Ocena varne navezanosti je bila pridobljena s korelacijo med opisom otroka po ocenjevanju z AQS in razvrstitvenim kriterijem ekspertov za prototipično varno navezanega otroka (Waters, 1995). Rezultati se lahko gibajo v razponu med $+1,00$ za popolnoma varno navezanega otroka in $-1,00$ za najbolj ogroženo navezanega otroka. Ujemanje med ocenjevalci za pet neodvisnih razporeditev istih malčkov je preseglo standardno vrednost 0,75 (Peters, 2010).

\section{Postopek in pripomočki za ocenjevanje prijateljstva pri 9-letnih otrocih}

Raziskovalci so otroke pri starosti devet let dvakrat obiskali v šoli. Med prvim obiskom so zbrali sociometrične podatke, s katerimi so identificirali recipročna prijateljstva, med drugim obiskom pa so opazovali interakcijo med otrokom in njegovim najboljšim prijateljem.

\section{Sociometrična preizkušnja}

V sklopu večjega sociometričnega testiranja so bili vsi otroci v oddelku udeležencev naprošeni, naj pisno poimenujejo in razvrstijo svoje prijatelje v oddelku. Otroke so vprašali: »Kateri izmed sošolcev so tvoji prijatelji? Začni z imenom svojega najboljšega prijatelja in nato naštej še ostale.« Navedli so lahko toliko prijateljev, kot so želeli. Iz teh podatkov je bilo identificirano število recipročnih prijateljstev posameznega otroka, najvišje razvrščeni recipročni prijatelj udeleženca pa je bil zatem povabljen, da ob soglasju staršev sodeluje pri drugem obisku na šoli.

\section{Kakovost prijateljstva}

Prva ocena kakovosti prijateljstva je bila ob drugem obisku pridobljena z Vprašalnikom kakovosti prijateljstva (angl. Friendship Quality Questionnaire - FQQ; Parker in Asher, 1993), ki so ga otroci izpolnili tik pred opazovanjem. Vprašalnik je sestavljen iz 40 postavk, katerih strinjanje otroci ocenjujejo na 5-stopenjski lestvici (1 - sploh ne drži, 5 resnično drži). Otroci so pri izpolnjevanju vprašalnika mislili na najboljšega prijatelja, ki je bil določen s sociometrično preizkušnjo. Najboljši prijatelj otroka je bil tisti sošolec oz. sošolka, ki ga/jo je otrok imenoval kot najvišje uvrščenega izmed treh najtesnejših prijateljev in ki je otroka tudi sam recipročno imenoval kot enega od treh najtesnejših prijateljev. Ko med tremi najvišje razvrščenimi prijatelji ni 
bilo recipročne nominacije, je kot najboljši prijatelj sodeloval naslednji nominirani prijatelj, ki je ciljnega otroka recipročno nominiral kot prijatelja (ne glede na rang nominacije). Otroci so izpolnjevali personalizirane različice vprašalnika, ki so vključevale zapis imena najboljšega prijatelja pri vsaki od postavk (npr. »S Saro si poveva skrivnosti.«), s čimer so želeli preprečiti izpolnjevanje vprašalnikov za idealizirano prijateljstvo ali za kombinacijo več prijateljstev (Parker in Asher, 1993). Vprašalnik je sestavljen iz šestih podlestvic, in sicer druženje in prosti čas $(\alpha=0,75)$, potrditev in skrb $(\alpha=0,90)$, pomoč in vodenje $(\alpha=0,90)$, intimna izmenjava $(\alpha=0,86)$, konflikt in izdajstvo (obratno vrednotenje, $\alpha=0,84)$ in reševanje konfliktov $(\alpha=0,73)$ (Parker in Asher, 1993). Otrokov rezultat na vsaki podlestvici predstavlja povprečje njegovih ocen na pripadajočih postavkah. Skladno s predhodnimi študijami (Parker in Asher, 1993) je bil skupni rezultat za posameznega otroka izračunan kot povprečje rezultatov vseh podlestvic, višji rezultat pa nakazuje na višjo kakovost prijateljstva.

Kakovost prijateljstva je bila nato ocenjena še $z$ opazovanjem interakcij med otroki in njihovimi najboljšimi prijatelji med drugim obiskom na šoli. Vsak otrok in njegov najboljši prijatelj sta iz oddelka odšla v mobilni laboratorij. Otroci in prijatelji so sodelovali v 30-minutni snemani interakcijski epizodi, ki je bila sestavljena iz štirih različnih nalog iz področja sodelovanja, tekmovanja in reševanja problemov, ki so bile razvite za namen študije. Pri prvi nalogi sta morala prijatelja skupaj čim hitreje odgovarjati na vprašanja, zapisana na drsnicah, ki so se jima prikazovale skozi posebna očala (angl. View-Master game). Druga naloga je bila igranje namizne družabne igre ribolova, pri čemer je vsak izmed prijateljev dobil drugačna pisna navodila za igro. Tretja naloga je vključevala skupno načrtovanje zabave, četrta pa je bila igra ugibanja, med katero je eksperimentator zapustil sobo in tako ustvaril priložnost za goljufanje. Interakcija med otrokoma je bila nato kodirana $\mathrm{z}$ uporabo Ocenjevalne lestvice interakcije med otrokom in prijateljem (angl. Child-Friend Interaction Rating Scales - C-FIRS; Peters idr., 2007), ki je prilagojena različica Opazovalne lestvice kakovosti prijateljstva (angl. Observed Friendship Quality Scale-OFQS; Flyr idr., 1995). Kakovost interakcij je bila ocenjena na ravni diad ter individualno na ravni ciljnih otrok (tj. udeležencev iz prvega vala študije) in njihovih najboljših prijateljev. V pričujoči študiji smo se osredotočili na individualne ocene vedenja ciljnih otrok. Opazovalci so individualno interakcijo ciljnih otrok ocenili na osmih 5stopenjskih lestvicah (z izjemo lestvice goljufanja, ki je imela 3-stopenjsko ocenjevanje): pozitivno vedenje (deljenje stvari, pomoč prijatelju), vključenost (kazanje pozornosti in interesa), negativno vedenje (razdražljivost, vsiljivost), dominantno vedenje (ukazovalnost, vpliv ali nadzor nad igro), goljufanje (pri igri), motečnost (kričanje, uporaba nespodobnega jezika), podredljivost (podrejenost nadzoru vrstnika in sledenje vrstniku) in spretno vodenje (uporaba spretnih socialnih strategij za doseganje ciljev) (Deutz idr., 2015). Celostna presoja kakovosti prijateljstva je bila ocenjena posebej z lestvico splošne kakovosti prijateljstva (C-FIRS - QF), ki je dodaten del Ocenjevalne lestvice interakcije med otrokom in prijateljem (C-FIRS). Medtem ko se z ostalimi osmimi lestvicami ocenjuje konkretno opazno vedenje, pa se pri oceni z lestvico splošne kakovosti prijateljstva upošteva vse stvari, ki jih opazovalci opazijo na posnetku in oceni splošen vtis kakovosti prijateljstva. Ocena na lestvici splošne kakovosti prijateljstva predvideva, da je povprečno kakovostna interakcija med prijatelji višja kot povprečno kakovostna interakcija med otroki, ki niso prijatelji.

\section{Rezultati}

\section{Opisne statistike in mere oblike porazdelitve}

Za mere navezanosti in prijateljstva smo najprej preverili opisne statistike in oblike porazdelitve (tabela 1). Povprečni rezultat dosežkov otrok na Vprašalniku o navezanosti (AQS) je $M=0,24$, kar je nekoliko nižje kot povprečni rezultat dosežkov otrok AQS $(M=0,32 ; S D=0,16)$ v metaanalizi, ki jo je na normativnih vzorcih otrok naredil van IJzendoorn, s sodelavci (2004). Na dodatni opazovalni lestvici splošne kakovosti prijateljstva (C-FIRS - QF) je bilo $51 \%$ prijateljstev otrok ocenjenih kot nadpovprečno kakovostnih, $16 \%$ pa kot podpovprečno kakovostnih.

\section{Analiza dimenzionalnosti Ocenjevalne lestvice interakcije med otrokom in prijateljem (C-FIRS)}

Za Ocenjevalno lestvico interakcije med otrokom in prijateljem (C-FIRS) smo za osem lestvic individualne interakcije ciljnih otrok izvedli eksploratorno faktorsko analizo (EFA), s katero smo želeli reducirati število spremenljivk in na osnovi faktorskega modela izračunati dosežke na manjšem številu vsebinsko smiselnih faktorjev. Zaradi nezvezne narave podatkov smo uporabili metodo neuteženih najmanjših kvadratov. Pred izvedbo EFA smo ocenili primernost podatkov, ki je bila ustrezna

\section{Tabela 1}

Opisne statistike mer navezanosti malčka in staršev ter prijateljstva otrok

\begin{tabular}{lcccccccccc}
\hline Mera & $N$ & $M$ & $M d n$ & $S D$ & Min & Max & \multicolumn{1}{c}{$A s$} & $S E_{A s}$ & $S p l$ & $S E_{S p l}$ \\
\hline AQS & 129 & 0,24 & 0,26 & 0,26 & $-0,54$ & 0,72 & $-0,24$ & 0,21 & $-0,22$ & 0,42 \\
FQQ & 110 & 3,93 & 3,97 & 0,59 & 2,09 & 4,97 & $-0,41$ & 0,23 & $-0,16$ & 0,46 \\
St. prijat. & 114 & 3,75 & 3,76 & 1,85 & 0 & 9 & 0,17 & 0,23 & $-0,25$ & 0,45 \\
C-FIRS - QF & 113 & 3,41 & 4,00 & 0,99 & 1,00 & 5,00 & $-0,57$ & 0,23 & 0,09 & 0,45 \\
\hline
\end{tabular}

Opombe: AQS - Dosežki na Vprašalniku o navezanosti; FQQ - Dosežki na Vprašalniku kakovosti prijateljstva; Št. prijat. = število recipročnih prijateljev; C-FIRS - QF - Dosežki na lestvici splošne kakovosti prijateljstva, $A s=$ asimetričnost, $S p l=$ sploščenost. 


\section{Tabela 2}

Matrika uteži za lestvice individualne interakcije na Opazovalni lestvici interakcije med otrokom in prijateljem (C-FIRS), rotirana z Direct Oblimin rotacijo

\begin{tabular}{lcc}
\hline Lestvica & \multicolumn{2}{c}{ Faktor } \\
\cline { 2 - 3 } & $\begin{array}{c}\text { asocialni slog } \\
\text { interakcije }\end{array}$ & $\begin{array}{c}\text { prosocialni } \\
\text { slog } \\
\text { interakcije }\end{array}$ \\
\hline negativno vedenje & $\mathbf{0 , 8 7}$ & $-0,15$ \\
motečnost & $\mathbf{0 , 6 2}$ & $-0,08$ \\
dominantno vedenje & $\mathbf{0 , 5 7}$ & 0,07 \\
goljufanje & $\mathbf{0 , 5 0}$ & 0,08 \\
vključenost & 0,10 & $\mathbf{0 , 7 1}$ \\
pozitivno vedenje & $-0,06$ & $\mathbf{0 , 8 5}$ \\
spretno vodenje & $-0,03$ & $\mathbf{0 , 4 3}$ \\
\hline Lastna vrednost & 2,24 & 1,89 \\
\% celotne variance & $32 \%$ & $27 \%$ \\
Kumulativni \% variance & $32 \%$ & $59 \%$ \\
\hline
\end{tabular}

$\left(\mathrm{KMO}=0,61 ; \chi^{2}(21)=194,36, p<, 001\right)$. Graf drobirja je nakazoval na identifikacijo dveh faktorjev, analiza pa je pokazala na prisotnost treh faktorjev, katerih lastne vrednosti presegajo Kaiserjev kriterij. Prisotnost treh faktorjev je potrdila tudi vzporedna analiza, vendar je lestvica podredljivost pokazala šibko nasičenost $\mathrm{s}$ faktorji, zaradi česar smo jo izločili iz nadaljnjih analiz. Analiza s sedmimi lestvicami je pokazala vsebinsko jasno dvofaktorsko rešitev, zaradi česar smo se odločili za identifikacijo dveh faktorjev. Zaradi predvidevanja o medsebojni povezanosti posameznih vidikov socialnega vedenja smo izvedli poševnokotno rotacijo. V tabeli 2 so prikazane faktorske uteži po rotaciji.

Identificirana faktorja skupaj pojasnita $59 \%$ variance $\mathrm{v}$ ocenah individualne interakcije ciljnih otrok. Matrika uteži nakazuje na jasne ločnice med obema faktorjema, korelacija med faktorjema pa je bila nizka $(r=-0,003, p=0,98)$. Na podlagi pripadajočih lestvic bi lahko prvi faktor interpretirali kot asocialni slog interakcije $(\alpha=0,73)$ in drugi faktor kot prosocialni slog interakcije $(\alpha=0,68)$. Faktorski rezultati posameznih faktorjev so bili uporabljeni za ocenjevanje individualnega vedenja otrok $\mathrm{v}$ interakciji $\mathrm{z}$ najboljšimi prijatelji.

\section{Korelacije med spremenljivkami}

Varna navezanost malčkov je pomembno zmerno povezana $\mathrm{s}$ prosocialnim slogom interakcije otrok in $\mathrm{Z}$ dosežki na opazovalni lestvici splošne kakovosti prijateljstva (C-FIRS - QF), ne pa tudi z drugimi merami prijateljstva otrok. Prav tako so med posameznimi merami prijateljstva nekatere pomembne zmerne korelacije (tabela 3).

\section{Razlike med spoloma}

Da bi preučili razlike med spoloma $\mathrm{v}$ navezanosti in kakovosti prijateljstva, smo izvedli več ločenih $t$-testov za neodvisne vzorce. Pri Vprašalniku o navezanosti (AQS), kjer višji rezultat nakazuje na bolj varno navezanost, med rezultati malčkov $(M=0,22 ; S D=0,24)$ in malčic $(M=0,28$; $S D=0,29 ; t[127]=-1,20, p=0,23, d=0,23)$ ni bilo pomembnih razlik. Pri meri opazovane kakovosti prijateljstva (C-FIRS - QF) med rezultati fantov $(M=3,39 ; S D=1,00)$ in deklet $(M=3,42 ; S D=1,00 ; t[111]=-0,19, p=0,85, d=0,03)$ ni bilo pomembnih razlik. Tudi pri asocialnem $\left(M_{\text {fantje }}=0,07\right.$; $S D=0,81 ; M_{\text {dekleta }}=-0,07 ; S D=1,02 ; t[111]=-0,77$, $p=0,44, d=0,14)$ in prosocialnem $\left(M_{\text {fantje }}=-0,10 ; S D=0,89\right.$; $\left.M_{\text {dekleta }}=0,10 ; S D=0,89 ; t[111]=1,17, p=0,24, d=0,22\right)$ slogu interakcije med spoloma ni bilo razlik. Razlika med spoloma pa obstaja pri samooceni kakovosti prijateljstva, kjer so dekleta $(M=4,10 ; S D=0,56 ; t[108]=-2,85, p=0,005)$ dosegala pomembno višje rezultate kot fantje $(M=3,79$; $S D=0,59)$. Velikost učinka je bila zmerna $(d=0,54)$. Pri meri števila recipročnih prijateljstev med rezultati fantov $(M=3,73 ; S D=1,90)$ in deklet $(M=3,78 ; S D=1,80$; $t[114]=-0,15, p=0,64, d=0,03)$ ni bilo pomembnih razlik.

\section{Model povezanosti med zgodnjo navezanostjo in prijateljstvom otrok}

Izhajajoč iz predstavljenih rezultatov smo želeli preučiti, če lahko na podlagi zgodnje navezanosti malčkov napovemo število recipročnih prijateljev, ki jih imajo $\mathrm{v}$ srednjem otroštvu. Z modelom smo želeli odgovoriti na vprašanje, ali je kakovost prijateljskih odnosov mediator odnosa med zgodnjo varno navezanostjo in številom prijateljstev $\mathrm{v}$ srednjem otroštvu. Na podlagi preliminarnih analiz smo se odločili, da izmed mer kakovosti prijateljstva v model vključimo le sloge

\section{Tabela 3}

Korelacije med spremenljivkami navezanosti (AQS) in prijateljstva (FQQ, C-FIRS in sociometrična preizkušnja)

\begin{tabular}{lcccc}
\hline Mera & 1 & 2 & 3 & 4 \\
\hline 1. AQS & & & & \\
2. FQQ & 0,06 & & & \\
3. Št. prijat. & 0,17 & $0,25^{* *}$ & & \\
4. Asocialni slog interakcije & $-0,14$ & $-0,03$ & $-0,27^{* *}$ & \\
5. Prosocialni slog interakcije & $0,25^{* *}$ & 0,16 & 0,16 & $-0,03$ \\
6. C-FIRS - QF & $0,25^{* *}$ & 0,03 & $0,19^{*}$ & $-0,19^{*}$ \\
\hline
\end{tabular}

Opombe: AQS - Dosežki na Vprašalniku o navezanosti; FQQ - Dosežki na Vprašalniku kakovosti prijateljstva; Št. prijat. = število recipročnih prijateljev; C-FIRS - QF - Dosežki na lestvici splošne kakovosti prijateljstva."* $p<, 05 ;{ }^{* *} p<, 01$. 


\section{Slika 1}

Model poti za mediacijo med zgodnjo navezanostjo in prijateljstvom otrok.

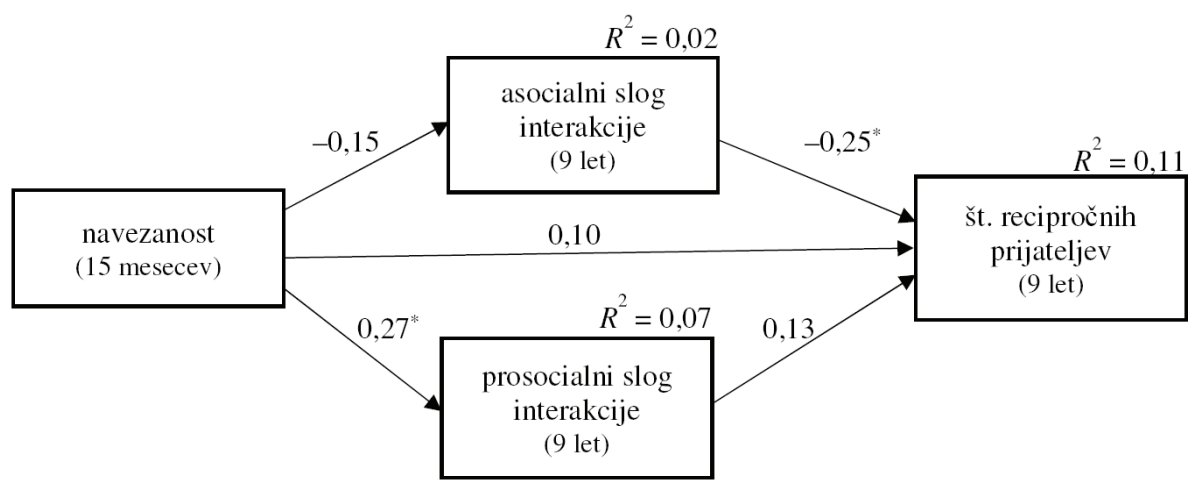

interakcije otrok, saj je splošna lestvica kakovosti prijateljstva otrok v osnovi podobna lestvicam, iz katere izhajajo slogi interakcije otrok, s tem da slednji podajajo vsebinsko natančnejšo in zanimivejšo oceno konkretnega opaznega vedenja otroka $\mathrm{v}$ interakciji $\mathrm{s}$ prijatelji (tj. prosocialni ali asocialni slog interakcije v primerjavi s splošno oceno bolj ali manj kakovostnega prijateljstva). Prav tako smo se zaradi potencialne napake pri samoocenjevanju in glede na starost otrok ob samooceni odločili, da v model vključimo zgolj oceno opazovanja. Na podlagi predstavljenih ugotovitev o povezanosti med zgodnjo navezanostjo $\mathrm{z}$ opazovanim prosocialnim slogom interakcije otrok ter povezanosti opazovanega asocialnega sloga interakcije $\mathrm{s}$ številom recipročnih prijateljev otrok, smo predpostavili mediacijski model povezanosti med zgodnjo navezanostjo v obdobju malčka in prijateljstvom otrok v srednjem otroštvu (slika 1). Analizo poti smo izvedli v statističnem okolju R s paketom lavaan (Rosseel, 2012), za ocene parametrov modela pa smo uporabili robustno metodo največjega verjetja (MLR).

Zgodnja navezanost se ni izkazala kot pomembno neposredno povezana $\mathrm{s}$ številom recipročnih prijateljev $(r=0,10 ; p=0,31)$. Slog interakcije otroka $\mathrm{v}$ odnosu do prijatelja v srednjem otroštvu pa se je izkazal kot mediator odnosa med navezanostjo otroka $\mathrm{v}$ obdobju malčka in številom recipročnih prijateljev, ki jih imajo $\mathrm{v}$ srednjem otroštvu. Bolj varna zgodnja navezanost pri 15 mesecih je bila zmerno pozitivno povezana s prosocialnim slogom interakcije otroka s prijateljem pri devetih letih $(r=0,27$; $p<0,05)$. Slog interakcije pa se je izkazal kot pomemben tudi pri številu recipročnih prijateljev, ki jih imajo otroci v srednjem otroštvu, saj je bil asocialen slog interakcije $(r=-0,25$; $p<0,05)$ povezan z manjšim številom recipročnih prijateljstev. Rezultati kažejo na pomemben posreden pozitiven učinek med zgodnjo navezanostjo in številom recipročnih prijateljstev, mediiran preko prosocialnega sloga interakcije $(\beta=0,04$, $p<0,05)$, medtem ko posreden učinek preko asocialnega sloga interakcije ni bil pomemben $(\beta=0,03, p=0,07)$. Posredna učinka nista bila statistično pomembno različna. Vsi učinki poti v modelu so relativno majhni ter skupaj pojasnijo $11 \%$ variance spremenljivke števila recipročnih prijateljstev.

\section{Razprava}

Na podlagi ugotovitev dosedanjih študij o povezanosti varne navezanosti s kakovostjo medvrstniških odnosov v predšolskem obdobju (npr. Lansford, 2004; McDowell in Parke, 2009) ter ugotovitev o porastu te povezanosti $\mathrm{z}$ naraščajočo starostjo otrok (Schneider idr., 2001), saj naj bi notranji delovni modeli $\mathrm{z}$ leti postali stabilnejši (Bowlby, 1982), smo pričakovali povezanost varne navezanosti s kakovostjo medvrstniških odnosov tudi v srednjem otroštvu. Vendar v nasprotju s pričakovanji naši rezultati kažejo, da varna navezanost malčkov ni bila pomembno povezana $s$ samoocenjeno kakovostjo prijateljstva pri devetih letih starosti otrok. Otroci v obdobju srednjega otroštva morda kakovosti prijateljstva ne opredeljujejo zgolj v okviru področij, ki so bila zajeta $\mathrm{v}$ samoocenjevalnem vprašalniku (npr. druženje, pomoč, konflikti in njihovo reševanje), temveč tudi z vidika števila prijateljev, ki jih imajo. Otrokom je v okviru prijateljstev namreč najprej pomembna materialna izmenjava, skupinska igra, vpliv vrstnikov na različnih področjih postaja vse večji, medtem ko se značilnosti prijateljstva, kot so intimnost, zvestoba, zaupanje in medsebojno razumevanje še razvijajo in postopno postajajo vedno pomembnejše (Marjanovič Umek in Zupančič, 2004). V tem obdobju je otrokom pomembna priljubljenost med vrstniki, bolj priljubljeni otroci pa imajo pogosto več priložnosti za oblikovanje prijateljstev in imajo tudi socialne veščine, ki so potrebne za sklepanje kakovostnejših prijateljstev (Parker in Asher, 1993). Otroci zato lahko večje število prijateljev lahko pojmujejo kot kazalnik kakovosti njihovih prijateljstev. Na navedeno kaže pomembna povezanost med samooceno kakovosti prijateljstva in številom recipročnih prijateljstev ter ugotovitev, da je vsak otrok v povprečju prejel 3,75 recipročnih nominacij prijateljev, glede na samooceno pa je bilo $47 \%$ prijateljstev ocenjenih kot nadpovprečno kakovostnih.

Število recipročnih prijateljstev otrok v srednjem otroštvu ni bilo pomembno povezano $\mathrm{z}$ navezanostjo malčkov. Povezanost med varno navezanostjo, številom prijateljstev, ki jih otrok razvije, in številom prejetih prijateljskih nominacij se je sicer pokazala v več opazovalnih študijah (npr. Clark in Ladd, 2000; Wood idr., 2004), ki pa so bile večinoma 
zasnovane prečno in so vključevale otroke $\mathrm{v}$ zgodnjem otroštvu. Povezavo med navezanostjo in socialnimi odnosi lahko, še posebej v vzdolžnih študijah, dodatno zmanjšuje nestabilnost navezanosti, ki je lahko posledica kontekstualnih dejavnikov (npr. socialnega, ekonomskega in kulturnega statusa družine) in življenjskih sprememb (npr. vrnitev mame na delo) (Schneider idr., 2001), kar je lahko ena izmed možnosti pojasnitve odsotnosti povezav, ki smo jih na podlagi prejšnjih ugotovitev pričakovali. Zlasti pri ogroženo navezanih otrocih je število prijateljev verjetno manj pomembno kot poznavanje kakovosti prijateljstev, saj imajo slednji manj tesnih in manj recipročnih prijateljstev, do prijateljev pa pogosto gojijo nerealistična pričakovanja (Selman in Schultz, 1990).

Da bi preučili povezanost navezanosti malčkov $\mathrm{Z}$ opazovano kakovostjo prijateljstva (pojmovano kot vedenje otroka $\mathrm{v}$ interakciji $\mathrm{z}$ najboljšim prijateljem) pri devetih letih, smo za oceno kakovosti prijateljstva najprej izvedli eksploratorno faktorsko analizo, s katero smo reducirali število spremenljivk in pridobili faktorske rezultate, ki smo jih uporabili v nadaljnjih analizah. $Z$ eksploratorno faktorsko analizo lestvic individualne interakcije smo identificirali dva faktorja. Izkazalo se je, da sta navezanost in prosocialni slog interakcije otrok pomembno pozitivno povezana. Bolj varna navezanost malčkov je torej povezana $\mathrm{z}$ višjo stopnjo izraženega prosocialnega individualnega vedenja $s$ prijateljem v srednjem otroštvu. Za malčke $\mathrm{z}$ varnim vzorcem navezanosti in za otroke $\mathrm{z}$ visoko izraženim prosocialnim slogom interakcije je značilno podobno vedenje v interakciji: vzpostavljanje očesnega in telesnega stika, navezovanje komunikacije, dejavnost $\mathrm{v}$ interakciji, kazanje naklonjenosti in iskanje bližine (Ainsworth idr., 2015; Flyr idr., 1995). Med varno navezanostjo in prosocialnim slogom interakcije tako obstaja povezanost, na podlagi katere ne moremo sklepati o vzročnosti, vendar v literaturi zasledimo jasne ugotovitve, da slog starševstva $\mathrm{v}$ obliki harmonične interakcije kot indikatorja varne navezanosti, ki jo otrok prevzame in posploši v vrstniško okolje, pozitivno vpliva na njegove medvrstniške odnose (Ladd, 2016; Youngblade in Belsky, 1992).

Preučili smo tudi povezanost opazovalne lestvice splošne kakovosti prijateljstva (C-FIRS - QF), ki je bila ocenjena ob zaključku opazovanja interakcije najboljših prijateljev, z zgodnjo navezanostjo. Lestvica pomeni presojo celostne kakovosti prijateljstva in ne zgolj posameznih vidikov opazovanega vedenja ali prevladujočega sloga interakcije. Neposredna povezanost med varno navezanostjo malčkov in opazovano kakovostjo prijateljstva otrok je bila pomembna, kar dopolnjuje nabor dosedanjih izsledkov študij, ki so dokazale povezanost med preučevanima konstruktoma (npr. Groh idr., 2014; LaFreniere in Sroufe, 1985; Pallini idr., 2014; Parker in Asher 1993; Peters, 2010; Schneider idr., 2001). Oblikovanje notranjih delovnih modelov in reprezentacij odnosov na podlagi zgodnjih izkušenj s primarnim staršem oz. skrbnikom je povezano z otrokovim kasnejšim načinom vstopanja $\mathrm{v}$ odnose in $\mathrm{s}$ kakovostjo odnosov $\mathrm{z}$ vrstniki. Vendar pa je bil koeficient povezanosti med navezanostjo malčkov in kakovostjo prijateljstva 9-letnih otrok kljub statistični pomembnosti, nizek. Eden izmed možnih vzrokov nižje povezanosti bi lahko bila tudi starost malčkov pri ocenjevanju navezanosti, saj starejši kot so malčki pri ocenjevanju navezanosti, močnejša je povezanost slednje s kakovostjo prijateljstva (Schneider idr., 2001). Prav tako tudi večina osrednjih značilnosti varne navezanosti - še posebej intimnost, varnost in zaupanje - postane osrednjega pomena v medvrstniških odnosih zlasti $\mathrm{v}$ obdobju mladostništva (Schneider idr., 2001). Pomembno je upoštevati tudi to, da je moč povezanosti med merami navezanosti in medvrstniških odnosov funkcija časovnega zamika med njimi. Bowlbyeva teorija trdi, da se motnje $\mathrm{v}$ zgodnji navezanosti odražajo v odnosih skozi celotno življenje, zaradi česar vzdolžni podatki, ki zajemajo več razvojnih stopenj, zagotavljajo bolj prepričljivo podporo teoriji povezanosti med navezanostjo in medvrstniškimi odnosi (Main idr., 1985; Schneider idr., 2001).

Ker pa se pojmovanje kakovosti prijateljstva pri otrocih in njihovih samoocenah skozi odraščanje spreminja in ker je konvergentna veljavnost samoocenjevanja lahko vprašljiva (Schneider idr., 2001), smo z namenom zmanjšanja napake ocenjevanja preverili tudi povezanost med opazovano kakovostjo prijateljstva in številom recipročnih prijateljskih nominacij. Tudi sicer uporaba treh različnih metod samoocenjevanje, opazovanje in sociometrična preizkušnja - zagotavlja širši vpogled v različne vidike medvrstniških odnosov. Ugotovili smo statistično pomembno negativno povezanost med številom recipročnih prijateljev in asocialnim slogom interakcije. Vedenje s prijatelji, za katerega je značilna vsiljivost, ukazovalnost, odklonsko vedenje in posnemanje prijateljev, je povezano $\mathrm{z}$ manjšim številom recipročnih prijateljstev. Tudi neodvisna splošna ocena opazovane kakovosti prijateljstva (C-FIRS - QF) se je izkazala kot statistično pomembno povezana $\mathrm{s}$ številom recipročnih prijateljstev. Z rezultati opazovanja kakovosti prijateljstva smo tako ugotovili, da so dobre socialne spretnosti otrok pomemben dejavnik pri sklepanju in ohranjanju recipročnih prijateljstev.

Preučili smo tudi razlike med spoloma $\mathrm{v}$ navezanosti in kakovosti prijateljstva. Med malčki in malčicami nismo ugotovili razlik v povprečni izraženosti varne navezanosti, kar je skladno z nekaterimi dosedanjimi ugotovitvami (npr. Peters, 2010; Van Bakel in Riksen-Walraven, 2004). Primerjava mer kakovosti prijateljstva otrok pa je pokazala na obstoj nekaterih razlik med spoloma. Medtem ko se pri opazovanju in številu recipročnih prijateljstev otrok niso pokazale razlike med spoloma, pa so deklice poročale o višji zaznani kakovosti prijateljstva, kar je v svoji raziskavi ugotovila tudi L. Phillipsen (1999). Med kakovostjo prijateljstva deklic in dečkov, ocenjene z opazovanjem, pa ni bilo razlik, kar je v nasprotju z izsledki nekaterih drugih raziskav (npr. Gullone in Robinson, 2005; Rice in Mulkeen, 1995), ki kažejo na skladnost med opazovanim vedenjem in poročanjem deklet o več pozitivnih značilnostih in višji kakovosti njihovih prijateljstev. Zaradi različnih ugotovitev raziskav težko delamo enoznačne zaključke o razlikah med spoloma $\mathrm{v}$ kakovosti prijateljstva, čeprav lahko pogosteje zasledimo izsledke raziskav, ki govorijo $\mathrm{v}$ prid kakovostnejšemu prijateljstvu pri dekletih (Bagwell in Schmidt, 2011). Vendar pa $\mathrm{v}$ raziskavah, ki so preučevale razlike med spoloma $\mathrm{v}$ povezavi z zgodnjo navezanostjo in kakovostjo prijateljstva ni bilo pomembne razlike med dečki in deklicami (Groh idr., 2014; Schneider idr., 2001). 
Da bi nadalje preverili povezave med navezanostjo malčkov in kakovostjo prijateljstva v srednjem otroštvu, smo predpostavili model poti, v katerem smo preučili mediacijsko vlogo kakovosti prijateljskih odnosov med varnostjo zgodnje navezanosti in številom recipročnih prijateljstev v srednjem otroštvu. Z modelom smo želeli natančneje preučiti, če imajo bolj kakovostne prijateljske interakcije pomembno mediacijsko vlogo med zgodnjo navezanostjo in številom prijateljev v srednjem otroštvu ter tako prispevajo k večjemu številu slednjih. Z modelom lahko pojasnimo $11 \%$ variance spremenljivke števila recipročnih prijateljstev. Izsledki zgodnejše raziskave sicer kažejo, da je zgodovina navezanosti pojasnila $13 \%$ variance kompetentnosti v prijateljskih odnosih v srednjem otroštvu (Sroufe idr., 1999), vendar pa navedenega rezultata ne moremo neposredno primerjati $\mathrm{z}$ ugotovitvami naše raziskave. Kompetentnosti v prijateljskih odnosih namreč ne moremo enačiti s številom recipročnih prijateljev otrok, prav tako pa je naša raziskava pokazala na pomemben posreden učinek navezanosti, saj je varianco spremenljivke števila recipročnih prijateljstev pojasnilo več prediktorjev skupaj. Kompetentnost v prijateljskih odnosih sicer zajema celosten način otrokovega reševanja temeljnih izzivov vzpostavljanja in ohranjanja prijateljstev z vrstniki, pri čemer pa najboljša recipročna prijateljstva predstavljajo najbolj intimen vidik odnosov z vrstniki (Kemple, 2004). Pri vpogledu $\mathrm{v}$ posamezne opazovane spremenljivke vidimo, da je bila navezanost pomemben napovednik prosocialnega sloga interakcije, prav tako pa je bil asocialni slog interakcije pomemben napovednik števila recipročnih prijateljstev. Zgodnja varna navezanost ni bila pomemben neposreden napovednik števila recipročnih prijateljev $\mathrm{v}$ srednjem otroštvu, pač pa je smo ugotovili sicer majhen, a pomemben posreden učinek varne navezanosti na število recipročnih prijateljstev, ki je bil posredovan preko kakovosti slogov interakcije oz. vedenja otrok med interakcijo $\mathrm{z}$ najboljšim prijateljem. To kaže na mediacijsko vlogo kakovosti interakcije $\mathrm{s}$ prijatelji med varno navezanostjo $\mathrm{v}$ obdobju malčka in številom prijateljev, ki jih imajo otroci v srednjem otroštvu. Zgodnja izkušnja varne navezanosti s staršem ali skrbnikom in oblikovanje notranjih delovnih modelov prispevata $\mathrm{k}$ oblikovanju pozitivnih reprezentacij o sebi, drugih in odnosih ter vpliva na otrokov način vstopanja $v$ odnose, kar se kaže v večji kakovosti interakcije otrok z drugimi vrstniki. Če so pričakovanja malčka o odzivnosti in podpori primarnega skrbnika potrjena, zagotavljajo ugoden notranji delovni model bližnjih odnosov, ki nato vpliva na odzivnost, naklonjenost in pozitivnost $\mathrm{v}$ interakciji s prijateljem. Prav vedenje otrok v interakciji z drugimi pa nadalje vpliva na število prijateljev, ki jih imajo. Če se bodo otroci s prijatelji vedli negativno, moteče, zelo dominantno ali popolnoma podrejeno, bodo verjetneje imeli manj recipročnih prijateljstev.

Če celostno preučimo pridobljene rezultate, slednji kažejo na zmeren učinek varne navezanosti malčkov na kakovost prijateljstev otrok, ki se kaže preko vedenja $\mathrm{v}$ interakciji $\mathrm{z}$ najboljšim prijateljem, pri čemer pa so vsi učinki v modelu poti relativno majhni. $Z$ modelom smo namreč pojasnili le majhen delež variance v številu recipročnih prijateljstev, ki pa prav tako predstavljajo zgolj enega, sicer najbolj intimnega, izmed vidikov kompetentnosti $\mathrm{v}$ odnosih $\mathrm{z}$ vrstniki. Tako ostaja še precej odprtih vprašanj, saj je tudi navezanost le eden izmed vidikov, ki vplivajo na medvrstniške odnose. Slednje podpirajo tudi izsledki raziskav, ki so pokazali, da je bila zgodovina navezanosti močan napovednik socialne kompetentnosti predvsem v kombinaciji z drugimi merami. Ko so avtorji poleg navezanosti v model sočasno vključili še druge vidike zgodnje nege in kakovosti družinskega okolja, se je stopnja pojasnjene variance povečala na $45 \%$ (npr. Sroufe, 1999; Sroufe idr., 2005). Verjetno je, da izkušnje, ki vodijo $\mathrm{k}$ varni navezanosti malčkov prav tako spodbujajo razvoj določenih socialnih in odnosnih spretnosti, ki so koristne pri prijateljstvih - nagnjenje k približevanju socialnim odnosom na prosocialen način ter pričakovanje recipročnosti (BoothLaForce idr., 2005).

Predlog za prihodnje raziskovanje bi bila vključitev najboljših prijateljev ciljnih otrok v vsa ocenjevanja, s čimer bi pridobili informacije o njihovi navezanosti na referenčno osebo v obdobju malčka in zaznavi kakovosti prijateljstva pri devetih letih. Poznavanje slednjih bi omogočilo globlji in večstranski vpogled $\mathrm{v}$ odnos povezanosti med zgodnjo navezanostjo in kasnejšo kakovostjo prijateljstev, saj bi morda $\mathrm{z}$ večjo gotovostjo identificirali tiste mehanizme in spremenljivke individualnega doprinosa in diadnih interakcij, ki pripomorejo $\mathrm{h}$ kakovostnemu prijateljstvu. $\mathrm{V}$ predpostavljeni preliminirani model bi $\mathrm{v}$ bodoče lahko vključili merjenje navezanosti in prijateljstva pri različnih starostih, s čimer bi zmanjšali časovni zamik med merjenji in primerjali odnos med konstrukti pri različnih starostih. Prav tako bi v nadaljnje raziskovanje lahko vključili mero kakovosti starševskega vedenja ter navezanosti med starši in otroki tudi v obdobju srednjega otroštva. Četudi so naša pričakovanja temeljila na predpostavki, da zgodnje izkušnje odnosov v precejšnji meri določajo kasnejšo kakovost prijateljstva, pa trenutni slog starševstva lahko igra pomembno vlogo. Izsledki raziskav, v katerih so preučevali zgodnjo in kasnejšo kakovost starševstva so pokazali, da slednja neodvisno napoveduje otrokovo socialno kompetentnost onkraj vpliva zgodnjega starševstva in navezanosti (npr. Raikes in Thompson, 2008; Sroufe idr., 1990). Vsekakor pa imajo pridobljene ugotovitve o vplivu navezanosti na kakovost prijateljstva uporabno vrednost, zlasti pri svetovanju in pomoči otrokom, ki bi lahko imeli zaradi izkušnje ogrožene navezanosti na področju prijateljstev in širših socialnih interakcij težave. Ena izmed možnosti bi lahko bila vključitev otrok v trening socialnih veščin ali v svetovanje s področja učinkovitih strategij vedenja $\mathrm{v}$ interakciji z drugimi otroki (npr. učinkovito reševanje konfliktov, sodelovalno vedenje, asertivnost ...). Prihodnje raziskovanje bi se lahko osredotočilo še na primerjavo relativnega prispevka lastnosti zgodnjega in kasnejšega starševstva k razvoju visoko kakovostnih prijateljstev. Prav tako bi bilo zanimivo podrobneje preučiti vlogo navezanosti na očeta $\mathrm{v}$ povezavi $\mathrm{s}$ kakovostjo prijateljstva otrok ter vključiti več mer odnosa med otrokom in starši oz. skrbniki (npr. slog starševstva, kognitivne reprezentacije odnosa), kar bi omogočilo preverjanje multiplih napovednikov odnosa med navezanostjo in prijateljstvom. 


\section{Literatura}

Ainsworth, M. D. S., Blehar, M. C., Waters, E. in Wall, S. N. (2015). Patterns of attachment: A psychological study of the strange situation. Psychology Press.

Bagwell, C. L. in Schmidt, M. E. (2011). Friendships in childhood and adolescence. The Guilford Press.

Berndt, T. J. (1996). Exploring the effects of friendship quality on social development. V M. W. Bukowski, A. F. Newcomb in W. W. Hartup (ur.), The company they keep: Friendships in childhood and adolescence (str. 346-365). Cambridge University Press.

Booth-LaForce, C. in Kerns, K. A. (2009). Child-parent attachment relationships, peer relationships and peergroup functioning. V K. H. Rubin, W. M. Bukowski in B. Laursen (ur.), Handbook of peer interactions, relationships, and groups (str. 490-507). The Guilford Press.

Booth-LaForce, C., Rubin, K. H., Rose-Krasnor, L. in Burgess, K. B. (2005). Attachment and friendship predictors of psychosocial functioning in middle childhood and the mediating roles of social support and self-worth. V K. A. Kerns in R. A. Richardson (ur.), Attachment in middle childhood (str. 161-188). Guilford Press.

Bowlby, J. (1973). Attachment and loss: Vol. 2. Separation: Anxiety and anger. Basic Books.

Bowlby, J. (1982). Attachment and loss: Vol. 1. Attachment. (2. izdaja). Basic Books.

Bretherton, I. (1985). Attachment theory: Retrospect and prospect. Monographs of the Society for Research in Child Development, 50(1/2), 3-35.

Bretherton, I. (2005). In pursuit of the internal working model construct and its relevance to attachment relationships. V K. E. Grossmann, K. Grossmann in E. Waters (ur.), Attachment from infancy to adulthood: The major longitudinal studies (str. 13-47). The Guilford Press.

Clark, K. E. in Ladd, G. W. (2000). Connectedness and autonomy support in parent-child relationships: Links to children's socioemotional orientation and peer relationships. Developmental Psychology, 36(4), 485-498.

Cohn, D. A. (1990). Child-mother attachment of six-year-olds and social competence at school. Child Development, 61(1), 152-162.

Deutz, M. H., Lansu, T. A. in Cillessen, A. H. (2015). Children's observed interactions with best friends: Associations with friendship jealousy and satisfaction. Social Development, 24(1), 39-56.

Flyr, M. L., Howe, T. in Parke, R. D. (1995). Observed friendship quality scale. [Neobjavljen sistem kodiranja]. University of California.

Groh, A. M., Fearon, R. P., Bakermans-Kranenburg, M. J., van IJzendoorn, M. H., Steele, R. D. in Roisman, G. I. (2014). The significance of attachment security for children's social competence with peers: A meta-analytic study. Attachment and Human Development, 16(2), 103-136.

Gullone, E. in Robinson, K. (2005). The Inventory of Parent and Peer Attachment - Revised (IPPA-R) for children: A psychometric investigation. Clinical Psychology and Psychotherapy, 12(1), 67-97.
Kemple, K. M. (2004). Let's be friends: Peer competence and social inclusion in early childhood programs. Teachers College Press.

Kerns, K. A. in Brumariu, L. E. (2016). Attachment in middle childhood. V J. Cassidy (ur.), Handbook of attachment: theory, research and clinical applications (str. 349-365). Guilford.

Ladd, G. W. (2016). Themes and theories: Perspectives on processes in family-peer relationships. V Parke, R. D. in Ladd, G. W. (ur.), Family-Peer Relationships: Models of linkage (str. 1-34). Routledge.

LaFreniere, P. J. in Sroufe, L. A. (1985). Profiles of peer competence in the preschool: Interrelations between measures influence of social ecology and relation to attachment history. Developmental Psychology, 21(1), 56-69.

Lansford, J. E. (2004). Links between family relationships and best friendships in the United States and Japan. The International Journal of Aging and Human Development, 59(4), 287-304.

Main, M., Kaplan, N. in Cassidy, J. (1985). Security in infancy, childhood and adulthood: A move to the level of representation. Monographs of the Society for Research in Child Development, 50(1/2), 66-104.

Marjanovič Umek, L. in Zupančič, M. (2004). Socialni in moralni razvoj v zgodnjem otroštvu. V L. Marjanovič Umek in M. Zupančič (ur.), Razvojna psihologija (str. 363-381). Znanstvenoraziskovalni inštitut Filozofske fakultete.

McDowell, D. J. in Parke, R. D. (2009). Parental correlates of children's peer relations: An empirical test of a tripartite model. Developmental Psychology, 45(1), 224-235.

Pallini, S., Baiocco, R., Schneider, B. H., Madigan, S. in Atkinson, L. (2014). Early child-parent attachment and peer relations: A meta-analysis of recent research. Journal of Family Psychology, 28(1), 118-123.

Park, K. A. in Waters, E. (1989). Security of attachment and preschool friendships. Child Development, 60(5), 1076-1081.

Parker, J. G. in Asher, S. R. (1993). Friendship and friendship quality in middle childhood: Links with peer group acceptance and feelings of loneliness and social dissatisfaction. Developmental Psychology, 29(4), 611-621.

Peters, E. (2010). Friendships in middle childhood: Links with psychobiology, parenting and peer group functioning [Neobjavljena doktorska disertacija]. Radboud Universiteit Nijmegen.

Peters, E., Van den Bosch, N. in Riksen-Walraven, J. M. A. (2007). The Child-Friend Interaction Rating Scales (CFIRS). Behavioural Science Institute.

Phillipsen, L. C. (1999). Associations between age, gender, and group acceptance and three components of friendship quality. Journal of Early Adolescence, 19(4), 438-464.

Raikes, H. A. in Thompson, R. A. (2008). Attachment security and parenting quality predict children's problem-solving, attributions, and loneliness with peers. Attachment and Human Development, 10(3), 319-344.

Rice, K. G. in Mulkeen, P. (1995). Relationships with parents and peers: A longitudinal study of adolescent intimacy. Journal of Adolescent Research, 10(3), 338-357. 
Rosseel, Y. (2012). lavaan: An R Package for Structural Equation Modeling. Journal of Statistical Software, 48(2), 1-36.

Scharf, M. (2014). Children's social competence within close friendship: The role of self-perception and attachment orientations. School Psychology International, 35(2), 206-220.

Scharf, M., Kerns., K. A., Rousseau, S. in Kivenson-Baron, I. (2016). Mother-child attachment and social anxiety: Associations with friendship skills and peer competence in Arab children. School Psychology International, 37(3), 271-288.

Schneider, B. H., Atkinson, L. in Tardif, C. (2001). Childparent attachment and peer relations: A quantitative review. Developmental Psychology, 37(1), 86-100.

Schwarz, B., Stutz, M. in Ledermann, T. (2012). Perceived interparental conflict and early adolescents' friendships: The role of attachment security and emotion regulation. Journal of Youth and Adolescence, 41(9), 1240-1252.

Selman, R. L. in Schultz, L. H. (1990). Making a friend in youth: Developmental theory and pair therapy. University of Chicago Press.

Sroufe, L. A. (1983). Infant-caregiver attachment and patterns of adaptation in preschool: The roots of maladaptation and competence. V M. Perlmutter (ur.), Minnesota symposium in child psychology (str. 41-81). Erlbaum.

Sroufe, L. A., Egeland, B. in Carlson, E. (1999). One social world: The integrated development of parent-child and peer relationships. V W. A. Collins in B. Laursen (ur.), Relationships as developmental contexts: The Minnesota Symposia on Child Psychology, vol. 30 (str. 241-261). Erlbaum.

Sroufe, L. A., Egeland, B., Carlson, E. in Collins, W. A. (2005). Placing early attachment experiences in developmental context. V K. E. Grossmann, K. Grossmann in E. Waters (ur.), Attachment from infancy to adulthood: The major longitudinal studies (str. 48-70). The Guilford Press.

Sroufe, L. A., Egeland, B. in Kreutzer, T. (1990). The fate of early experience following developmental change: Longitudinal approaches to individual adaptation in childhood. Child Development, 61(5), 1363-1373.

Sroufe, L. A. in Waters, E. (1977). Attachment as an organizational construct. Child Development, 48(4), 1184-1199.

Van Bakel, H. J. in Riksen-Walraven, J. M. (2002). Parenting and development of one-year-olds: Links with parental, contextual and child characteristics. Child Development, 73(1), 256-273.

Van Bakel, H. J. in Riksen-Walraven, J. M. (2004). AQS security scores: What do they represent? A study in construct validation. Infant Mental Health Journal, 25(3), 175-193.

van IJzendoorn, M. H., Vereijken, C. M. J. L., BakermansKranenburg, M. J. in Riksen-Walraven, J. M. (2004). Assessing attachment security with the Attachment Q Sort: Meta-analytic evidence for the validity of the observer AQS. Child Development, 75(4), 1188-1213.

Waters, E. (1995). Appendix A: The Attachment Q-set (version 3.0). Monographs of the Society for Research in Child Development, 60(2/3), 234-246.
Waters, E., Wippman, J. in Sroufe, L. A. (1979). Attachment, positive affect, and competence in the peer group: Two studies in construct validation. Child Development, 50(3), 821-829.

Wood, J. J., Emmerson, N. A. in Cowan, P. A. (2004). Is early attachment security carried forward into relationships with preschool peers? British Journal of Developmental Psychology, 22(2), 245-253.

Youngblade,L. M.in Belsky, J.(1992). Parent-child antecedents of 5-year-olds' close friendships: A longitudinal analysis. Developmental Psychology, 28(4), 700-713.

Youngblade, L. M., Park, K. A. in Belsky, J. (1993). Measurement of young children's close friendship: A comparison of two independent assessment systems and their associations with attachment security. International Journal of Behavioral Development, 16(4), 563-587. 